PART I

National Identity 



\title{
Taiwan's National Identity and Cross-Strait Relations
}

\author{
Yi-huah Jiang
}

The situation of the Taiwan Strait has remained one of the most worrisome flash points on the globe since the Second World War. Even in the aftermath of the collapse of the Soviet bloc, the possibility of a military confrontation between communist China and the United States still remains. The 1995-96 missile-test crisis following former president Lee Teng-hui's visit to the United States was a testimony to how sensitive cross-Strait relations were and how flammable the political situation could become overnight.

In the past eight years (2008-16), cross-Strait relations were relatively peaceful compared to how they had been under former president Chen Shui-bian (20002008). This peaceful coexistence was primarily a result of President Ma Ying-jeou's mainland policy, which replaced "confrontation" with "engagement," implemented the "three direct links" (postal, transportation, and trade) between mainland China and Taiwan, and successfully procured the Economic Cooperation Framework Agreement (ECFA) and another twenty bilateral agreements with mainland China, covering areas that ranged from trade promotion to crime prevention, food safety, environmental protection, and transportation cooperation.

Nevertheless, Ma's mainland policy was fiercely criticized by the Democratic Progressive Party (DPP) and was frequently denigrated as a betrayal of Taiwan's real interests. The critics accused Ma's government and the Nationalist Party (the Kuomintang, KMT) of "selling Taiwan to China" on the grounds that the KMT was a prounification party, and Ma himself never identified with Taiwan. The accusation, though emotional and exaggerated, had its political effect among those who did not benefit from his mainland policy. The general discontent with that policy, together with the poor performance of the government and nasty intraparty 
cleavages (first between Ma and Wang Jin-pyng, then between Eric Chu and Hung Shiu-chu), resulted in the unprecedented defeat of the KMT in the 2014 local elections and the 2016 presidential election.

The DPP's landslide victory in the 2016 election may become a turning point in the long-term development of cross-Strait relations. The DPP has traditionally favored a de jure Taiwan independence policy, and the newly elected president, Ms. Tsai Ing-wen, is generally regarded as a careful but uncompromising advocate of the independence cause. She was the drafter of former Republic of China (ROC) president Lee Teng-hui's "two states" concept (liang guo lun) and was a strong supporter of Chen Shui-bian's “one country on each side [of the Taiwan Strait]" (yi bian yi guo) concept, both of which describe Taiwan and China as two different countries and counter the notion of a single China. During the presidential election, Tsai asserted that most Taiwanese do not identify themselves with China and that "most youths are naturally inclined to Taiwan independence." Whether Tsai's policy toward mainland China will change Ma's legacy and what the consequences will be for cross-Strait relations (and East Asian security) deserve a thorough examination.

Issues of national identity and unification/independence are always conceived as critical in Taiwanese politics and cross-Strait relations. This chapter first explains the meaning of national identity in the context of Taiwanese politics, examines the different ways of measuring national identity in Taiwan, and shows that no matter which measurement is adopted, Taiwanese identification has risen precipitately in the past two decades. I then focus on the "one-China principle," an issue that I think more important and worthy of attention than the issue of national identity or the unification/independence choice. Finally I analyze what the scenarios of cross-Strait relations will be after the 2016 election, keeping in mind that cross-Strait relations are not merely bilateral, since they involve Taiwan, mainland China, and the United States in a strategic triangle relationship, and conclude with suggestions for improving cross-Strait relations.

\section{CHANGING NATIONAL IDENTIFICATION IN TAIWAN}

Theories of nationalism and national identity have been extensively discussed in Taiwan in recent decades. ${ }^{1}$ Roughly speaking, there are two major schools concerning the meaning of a nation: the modernist and the primordial. The modernist school argues that the nation is a modern political construction arising in the process of state building. Since the global system of nation-states was formed no earlier than the seventeenth century, the modernists argue that the concepts of nation, nationalism, and national identity are all very novel socially constructed forms. On the other hand, the primordial school maintains that although the nation-state system is a modern phenomenon the nation has an antecedent objective 
existence that summons people's loyalty and identity, mostly on the bases of shared history, myth, genealogical relations, or religious belief, long before the modern state learns how to mobilize its citizens in the name of a fatherland. ${ }^{2}$

Most Taiwanese scholars tend to buy the modernist argument and see the "Taiwanese people" as a modern social construction emerging in the process of decolonization and democratization. They tend to agree on the following points: (1) A nation is an aggregate of persons who associate with each other by common descent, language, religion, or history, although the sense of communion may be imagined rather than actual. (2) National identity is a feeling that one has toward one's imagined community, the fundamental features of which include a homeland, a people, a common historical memory, and a common public culture. (3) Taiwanese identity is the source of Taiwanese nationalism and the Taiwanese nationalist movement, which pursues the political goal of Taiwanese independence. ${ }^{3}$ As the building of a nation-state is usually described as the highest accomplishment of nationalism, Taiwanese nationalist scholars have little hesitation in accepting nationalism as a doctrine that holds that "the political and the national unit should be congruent," as Ernest Gellner succinctly puts it. ${ }^{4}$

Three different methods of measuring Taiwanese national identity are designed and widely employed in Taiwan. The first targets the consciousness of being Taiwanese as a distinct concept from that of being Chinese. The second addresses Taiwanese people's attitude toward unification with mainland China or a de jure independence of the island state. The third examines the extent to which respondents consider themselves to be Taiwanese nationalists or Chinese nationalists. I will analyze all the three methods in order and will argue that none proves a perfect measurement, though each serves a specific function in understanding Taiwanese people's collective consciousness.

Let us begin with the most popular method of understanding Taiwan's national identity-considering oneself Taiwanese versus Chinese. It is assumed that those who declare themselves to be Taiwanese only are identified with a political community called Taiwan; those who declare themselves to be Chinese only have a Chinese national identity; and those who say they are both Taiwanese and Chinese have a dual national identity.

According to a systematic survey conducted by the Election Study Center at National Chengchi University, the self-identity of Taiwan's residents has shifted spectacularly from a predominantly Chinese identity in the early years of democratization to a prevailing Taiwanese identity in Ma's second term of presidency. As figure 1 indicates, in the early 1990 s nearly 25.5 percent of those polled by this survey answered that they perceived themselves as exclusively Chinese. The percentage dropped to 10.6 percent in 2001 at the beginning of Chen Shui-bian's administration and stood at only 3 percent in 2016. On the other hand, those who considered themselves exclusively Taiwanese rose dramatically from 17.6 percent 


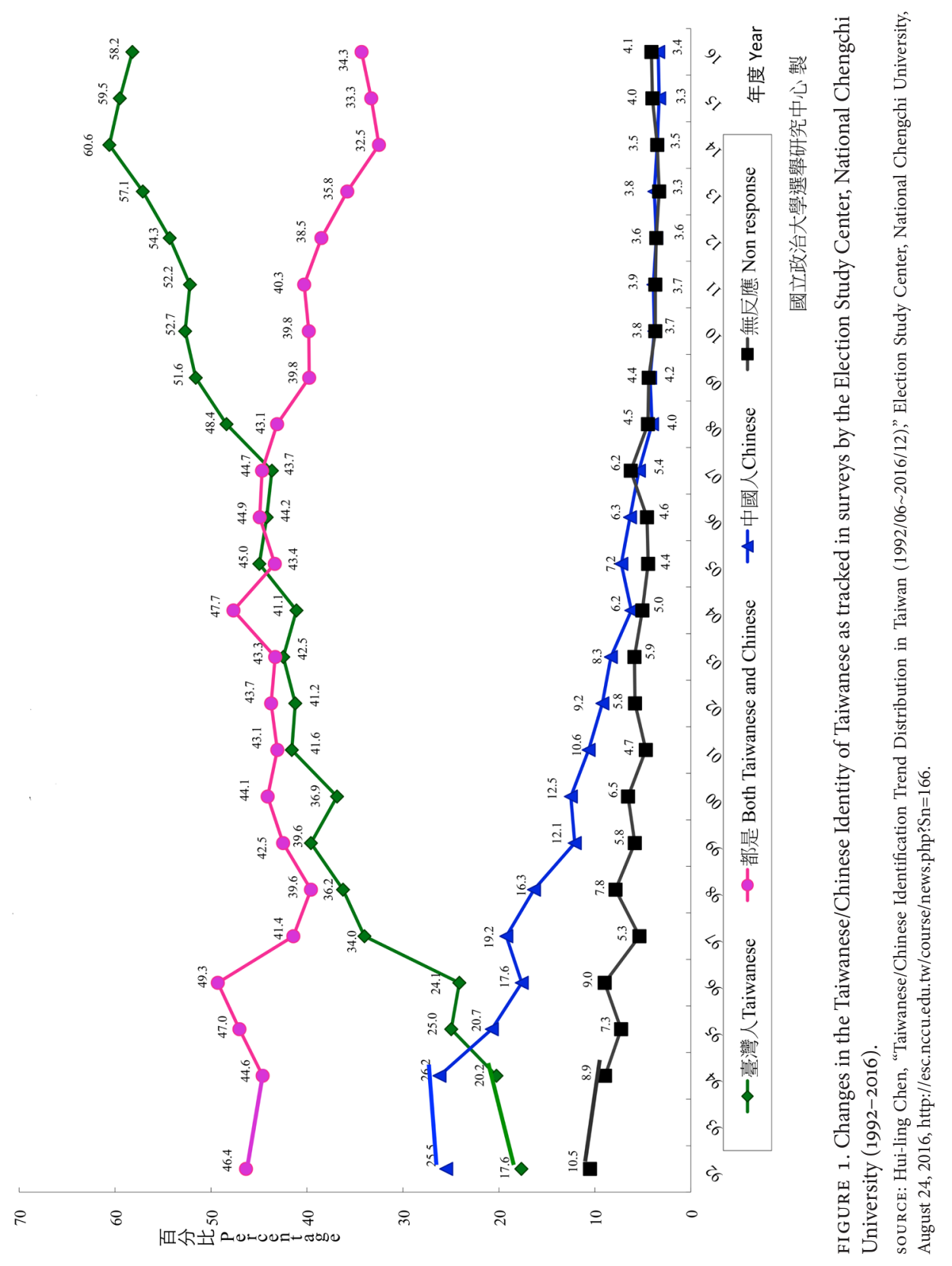


in 1992 to 41.6 percent in 2001 , and to 59.3 percent in 2016 . That is to say, nearly two-thirds of Taiwan's population identify themselves exclusively Taiwanese now, and a great portion of this increase occurred during Ma Ying-jeou's administration. The proportion who regarded themselves as both Taiwanese and Chinese also dropped steadily from 46.4 percent to 33.6 percent in the same period. ${ }^{5}$

I have pointed out elsewhere that the classification of Taiwanese/Chinese/both is not an effective measurement of Taiwan's national identity, although it reveals some important information about the shift of the collective self-consciousness of Taiwanese. One major reason is that the term Chinese (Zhongguoren) is ambiguous in Mandarin. It can be used to designate a person who identifies with Chinese culture without referring to any specific body politic, or it can be understood to designate a person who identifies with either the ROC or the PRC. When a person responds to the question "Are you a Chinese or a Taiwanese?" with the answer "I am a Chinese," there is no way to determine whether he or she is referring to cultural identity or political identity. People living in mainland China, Taiwan, Hong Kong, or even oversea Chinese communities will have no difficulty regarding themselves as "Chinese" if they are thinking in cultural or ethnical terms. If we understand Chinese identity in cultural terms, as many scholars did when they cited the poll, then the category of "being Chinese" cannot be understood to be the people who identify with the PRC, and the category of being "both Chinese and Taiwanese" cannot be described as dual national identity or confusion of national identity. The latter may be simply an expression of one's multiple cultural affinities rather than one's political identity. ${ }^{6}$

The second approach to understand Taiwanese people's identity is to survey their attitude toward unification and independence. It is assumed that if a person prefers unification with mainland China to Taiwanese independence, he or she should be regarded a person with Chinese national identity. The opposite would describe a person with a Taiwanese national identity. The research team of the Election Study Center further divided the binary unification/independence option into a six-option classification. The result is shown in figure 2.

If we put the "independence as soon as possible" and "maintain status quo, move toward independence" together, put the "unification as soon as possible" and "maintain status quo, move toward unification" together, and put the "maintain status quo indefinitely" and "maintain status quo, decide at later date" together, we find that people in favor of independence rose from over 11 in 1994 to almost 23 percent in 2016. Those in favor of unification declined steadily from 20 percent in 1994 to slightly over 10 percent in 2016. Those favoring the status quo also rose from around 48 percent in 1994 to almost 60 percent in 2016, remaining the greatest share of the population in the past two decades. ${ }^{7}$

The survey is important for our understanding of Taiwanese's preferences on the issue of "unification/independence," but it is more about Taiwanese people's 


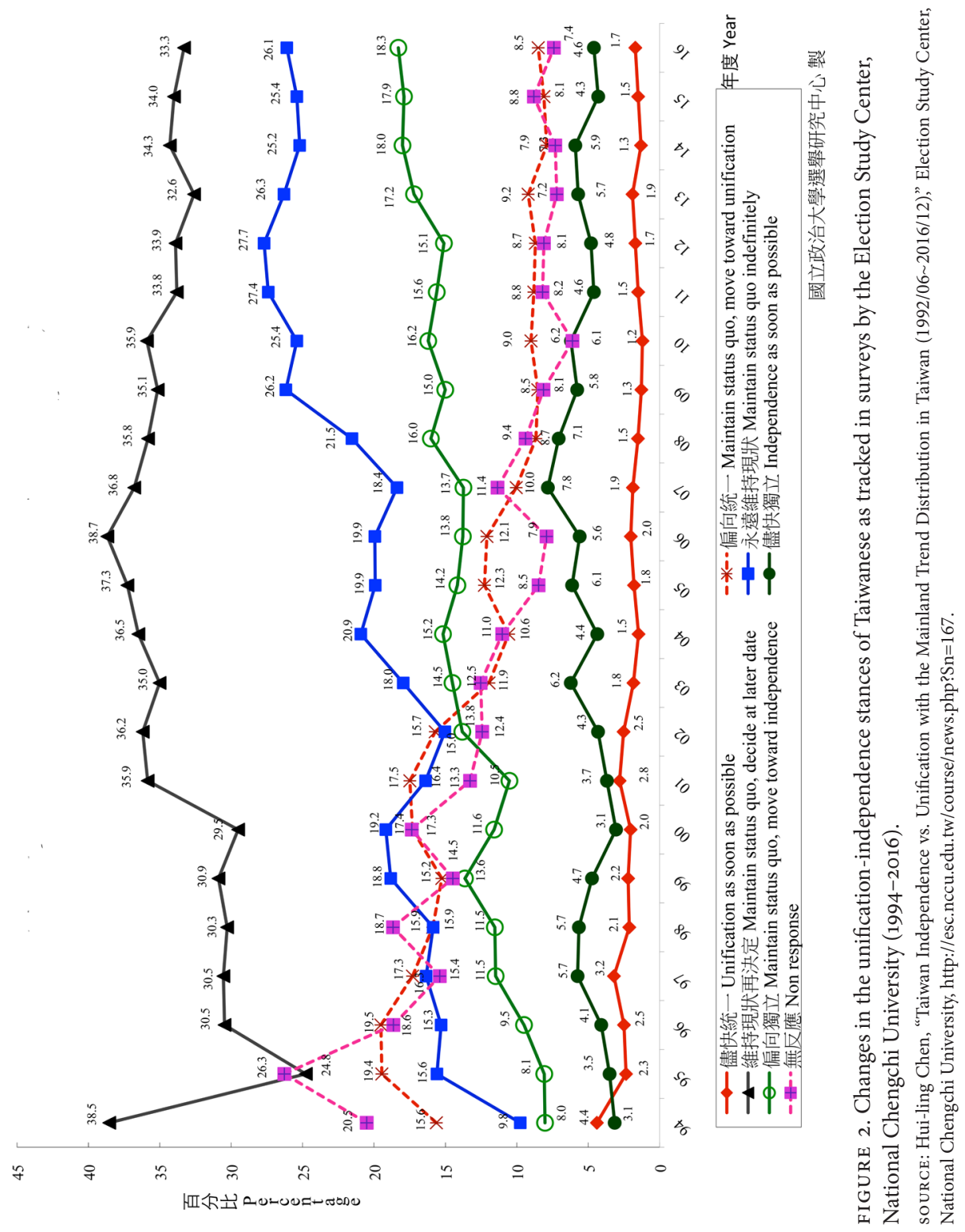


choice of the future than an expression of their national identity. These two questions are closely related but different. Especially when more than 60 percent of the respondents answer that they prefer the status quo, it is difficult to say what kind of national identity "the status quo" means. ${ }^{8}$ I will come back to the diverse interpretations of "the status quo" later.

The problem with the previous two methods has been noticed by many scholars. Wu Naiteh argues that national identity as conceived in the unification/independence choice can be influenced by unfavorable, external political circumstances, and people will accordingly modify their attitude to a more pragmatic standpoint for the short term. To explore the hidden, long-term view of national identity, he designed a questionnaire with two key questions: (1) If a Taiwanese independence would not precipitate a war, then would you agree that Taiwan should become an independent country? (2) If Taiwan and China were to become comparably developed economically, socially, and politically, would you agree that the two sides of the Taiwan Strait should be united into one country?"

Wu classifies those who say "yes" to the first question but "no" to the second as "Taiwanese nationalists" (those who pursue independence under favorable conditions and refuse to unify with China even if the latter becomes as well developed as Taiwan). The respondents who say "no" to the first question but "yes" to the second are classified as "Chinese nationalists" (those who expect unification under a favorable situation but oppose Taiwanese independence even if no war will happen). Those who say "yes" to both questions are described by Wu as "pragmatists," while those who say "no" to both questions are termed "conservatives" (table 1).

From their survey, Shen and $\mathrm{Wu}$ discovered that the proportion of Taiwanese nationalists rose considerably from 9.3 percent in 1992 to 27.7 percent in 2005 but seemed to stop short of a 30 percent ceiling. On the other hand, the proportion of Chinese nationalists declined steadily from 38 percent in 1992 to 13 percent in 2005. The trend of a rising Taiwanese identity and a declining Chinese identity is consistent with the findings of the other two methods discussed above. What bothered Shen and $\mathrm{Wu}$, however, was that there has always been a significantly large group of pragmatists who "are willing to accept an independent Taiwan if their security is not endangered, and they are likewise willing to accept unification with China if there are no negative economic or political repercussions." Their proportion was 25 percent in 1992 and 30 percent in 2005, with a peak of nearly 40 percent in 1996, when cross-Strait relations reached the most dangerous point since the 1950s. Shen and Wu could not tell whether these pragmatists had a dual national identity or no particular national identity at all, so they decided to leave this puzzle for further study. ${ }^{10}$

I think Wu's questionnaire is helpful in trying to identify those who clearly and strongly wish to pursue their nationalist cause, either independence or unification. Yet it would be more convincing if Wu could add two more questions to it: (3) If a 
TABLE 1 Taiwanese national identities (a simplified version of $\mathrm{Wu}$ and Shen's original classification of national identities in Taiwan, 1992-2005)

\begin{tabular}{|c|c|c|}
\hline & $\begin{array}{l}\text { Accept unification if no } \\
\text { disparity between Taiwan } \\
\text { and China }\end{array}$ & $\begin{array}{l}\text { Reject unification even if no } \\
\text { disparity between Taiwan and } \\
\text { China }\end{array}$ \\
\hline $\begin{array}{l}\text { Accept Taiwanese independence } \\
\text { if no war happens }\end{array}$ & Pragmatists & Taiwanese Nationalists \\
\hline $\begin{array}{l}\text { Reject Taiwanese independence } \\
\text { even if no war happens }\end{array}$ & Chinese Nationalists & Conservatives \\
\hline
\end{tabular}

sources: Shiau-chi Shen and Nai-teh Wu, "Ethnic and Civic Nationalisms: Two Roads to the Formation of a Taiwanese Nation," in The “One China” Dilemma, ed. Peter C. Y. Chow (New York: Palgrave Macmillan, 2008), 122.

Taiwanese independence would precipitate a war, then would you agree that Taiwan should become an independent country? (4) If Taiwan and China were not to become comparably developed economically, socially, and politically, would you agree that the two sides of the Taiwan Strait should be united into one country? It is only with a combination of (1) and (4) can we identify the real Chinese nationalists (those who reject independence even if no war happens and who want to unify with China even if the political, social, and economic conditions across the Strait cannot be compatible), and only with a combination of (2) and (3) can we identify the real Taiwanese nationalists (those who reject unification even if conditions across the Strait are similar and who are determined to pursue independence even if it will cause a war). ${ }^{11}$

The real problem, however, is that Shen and Wu's survey still cannot explain the existence of a substantial number of "pragmatic" respondents and instead beats around the bush by looking for the principled "nationalists." If the so-called pragmatists have stayed the greatest portion of the whole population for decades, isn't it a clear indication that the questionnaire itself may be misleading in the inquiry concerning national identity? It is a good questionnaire to detect the degree of a respondent's determination to seek independence or unification but not a satisfactory measurement of one's national identity. For instance, one might have no doubt about one's political identity with the ROC but refuse to fight for Taiwanese independence or refuse to unify with mainland China under unfavorable conditions, and we could not say that this person did not have a political identity. After all, "having an identity" is different from "having a strong identity."

For this reason, I have suggested another method of investigating Taiwan's national identity. Liu I-chou suggested many years ago that we should try to understand people's national identity according to their perception of the territory of their country and who their compatriots are. The questions based on this line of thinking would be: (1) Do you think that the territory of your country includes 
mainland China or only Taiwan? (2) Do you think that your compatriots include those living in mainland China or only those living in Taiwan? Those who recognize only Taiwanese territory and compatriots as their own have a Taiwanese (or ROC) national identity. By contrast, those who include mainland China in their territory and mainland Chinese as their compatriots have a Greater Chinese national identity. ${ }^{12}$

When Liu administered this questionnaire to Taiwan residents in 1998, about 77 percent of respondents had a Taiwanese identity, and about 9 percent had a Greater Chinese identity. The rest were of mixed identity or did not answer. Unfortunately, the questionnaire was not readministered in ensuing years. ${ }^{13}$ My conjecture is that, after more than a decade of increasing Taiwanese consciousness, the proportion of those with a Taiwanese national identity has grown even greater and now probably makes up more than 85 percent of the population, while the proportion of those with a Greater Chinese national identity may now be less than 5 percent. Liu's measure is the most appropriate way to describe the national identity of Taiwanese people. The large majority of Taiwanese who identify themselves with the country existing on the island may differ among themselves in their cultural and ethnic identity (their sense of being Taiwanese or Chinese or both), or in their ideas as to whether Taiwan should pursue de jure independence or unify with mainland China in the future), or in the degree of their patriotism regarding the ROC (or Taiwan), but they identify with the ROC (or Taiwan) in the strictly political sense. The few who identify with mainland China (or a greater China) should be respected, as long as they abide by the constitution and laws of the ROC.

In other words, national identity in Taiwan is not as divisive an issue as many scholars imagine or describe if we understand the concept correctly. Taiwanese may differ in their sense of cultural belonging, ethnic origins, political choices, or determination to pursue their ideals, just as they differ on public policy issues, taste of food and clothes, style of entertainment, obsession with sport, philosophy of life, and so on. But as a popular Taiwanese writer once remarked, "Taiwan is one hundred percent a country. If it is not a country, what is a country?" ${ }^{14}$ Most controversies arise not from the question of whether Taiwan is a country but from the question of whether it should be called "the Republic of China" or simply "Taiwan." In other words, what makes the issue of Taiwan's national identity complicated is not its boundary, population, or sovereignty but dispute over the "one-China" principle, to which we now turn.

\section{THE “ONE-CHINA” PROBLEM}

As noted in the previous section, some measures of national identity in Taiwan do not exactly reflect what they are purported to measure. The classification of "Taiwanese/Chinese/both" helps us realize how two different and overlapping 
cultures affect Taiwanese's self-perception, but it cannot be translated into a political identity that corresponds to a specific territory and sovereignty. The classification of unification/independence/status quo tells us what kind of political future Taiwanese want, but that wish makes sense only under the precondition that Taiwan is a political entity that can make the choice. The questionnaire combining "independence if no war" and "unification if China well developed" explores the factors that Taiwanese might consider when they face the choice of independence or unification. It may help us distinguish moderate nationalists from unyielding nationalists, but it is not a measurement of national identity per se.

If we stick to the core meaning of national identity (namely, a sense of belonging to a specific sovereign territory and a group of people with common life experience), it becomes clear that Taiwanese do know where their country is and who their compatriots are. A few do not agree with the overwhelming majority on this issue, but this is not a big problem. Taiwanese people may be divided on the issue of independence or unification, yet they are fully aware of their national identity. In other words, national identity is not a real issue in Taiwan. It is, unfortunately, many politicians' favorite means of political mobilization during elections.

Unification/independence is not a real issue either. The KMT is frequently described as prounification and the DPP as proindependence. That is true if we assume that they are faithful to their party platforms and that their candidates are arguing against each other for no other reason but the cause of unification or independence. Nevertheless, as all opinion polls show, more than 60 percent of Taiwanese want to maintain the status quo; and only about 24 percent favor an independence policy, and only 9 percent of them favor a unification policy. Aware of public opinion, neither the KMT nor the DPP has declared that it would implement a clear policy of unification or independence. On the contrary, both parties are busy persuading the people that they will do better than the other in maintaining the status quo. Politicians who do not adhere to the status quo but promote independence or unification are either targeting a specific electorate out of political calculation or committing political suicide.

If national identity is not a serious problem, and unification/independence is not an urgent choice, then what makes Taiwanese politics so turbulent and antagonistic? The answer has to do with the challenge of the "one-China policy" coming from the Chinese Communist Party (CCP) in mainland China.

Ever since 1949, when the CCP crushed the KMT in the civil war and forced the Nationalist government retreat to Taiwan, the communist government has declared that the People's Republic of China (PRC) is the only legitimate representative of China in the world; at the same time the defeated Nationalist government has maintained that it is the only legal representative of China. In the following decades, Beijing has consistently insisted on a "one-China principle," based on the premises that (1) there is only one China in the world; (2) Taiwan is part of China; 
and (3) the PRC is the only legitimate government to represent China. Springing from this principle, is an insistence on the policy that all countries seeking to establish diplomatic relations with the PRC must terminate official relations with the ROC. These countries must recognize the PRC as the only legitimate representative of mainland China and Taiwan, or at least acknowledge its claim on the issue.

The "one-China policy" is a zero-sum game between the PRC and the ROC. Whenever a country recognizes the legal status of the PRC, the ROC immediately cuts its diplomatic relations with that country, and vice versa. The policy also forces Taiwan gradually to adopt a defensive position in the international arena because it cannot afford to compete with China politically or economically.

Taiwan is fully aware of its difficult international situation under the isolation strategy of China. Particularly after the ban on cross-Strait tours was lifted in the late 1980s, the ROC found that there was no way of avoiding negotiation with the PRC with regard to administrative affairs. But when the PRC faced severe international sanctions as a result of the Tiananmen Square incident and saw proindependence forces gaining strength in Taiwan, it felt a need to adjust its Taiwan policy. That was the background for the "1992 Consensus" reached between the Straits Exchange Foundation (SEF, representing Taiwan) and the Association for Relations Across the Taiwan Straits (ARATS, representing mainland China).

The most important point of the 1992 Consensus is that the ROC and the PRC agree that there is only one China but also agree that each side can have its own interpretation of what "one China" means, so that they can go on to do functional work without being influenced by controversy about sovereignty. The announcement of the SEF on November 3, 1992, read as follows: "In the Hong Kong talks, the ARATS insisted that both parties should make 'public statements' on the issue of 'one China.' With the authorization from the Mainland Affairs Council, the SEF is agreeable to an oral statement of their respective interpretations. As to the content of this oral statement, we will express it in line with the Guidelines for National Unification and the resolution on the meaning of 'one China' adopted by the National Unification Council on August 1, 1992."15 This is the famous "one China, differing interpretations" (yizong gebiao) formula for dealing with the "one-China principle" asserted by Beijing: the ROC is willing to accept the principle that there is only one China in order to process cross-Strait affairs, but it reserves the right to interpret what "one China" means and, not surprisingly, sees itself rather than the PRC as the "one China."

The SEF's announcement was soon echoed by the ARATS, which declared: "The SEF officially has notified the ARATS that it received consent from the authorities concerned in Taiwan to 'an oral statement of their respective interpretations.' The ARATS fully respects and accepts the SEF's suggestion. . . . Now the ARATS wishes to inform the SEF of the salient points of its oral statement: Both sides of the Taiwan Strait insist on the one China principle and strive for national 
unification; however, the meaning of 'one China' shall not be involved in crossStrait talks of a functional nature." ${ }^{16}$ For reasons that we cannot elaborate here, the 1992 Consensus was not honored from 1993 to $2008 .{ }^{17}$ When Chen Shui-bian came to power in 2000, he even denied the existence of such a consensus. However, Ma Ying-jeou decided to resume the talks between the SEF and the ARATS on the basis of the 1992 Consensus after he was elected as the president in 2008. From then on, the new principle of "one China, differing interpretations" played a very important role in stabilizing cross-Strait relations and made possible the signing of twenty-one agreements between the two sides.

The 1992 Consensus was celebrated by the KMT as a milestone in the development of cross-Strait relations. It was also acknowledged in Assistant Secretary of State James Kelly's testimony before the US Congress and in Chairman Hu Jintao's telephone conversation with President George W. Bush. ${ }^{18}$ However, DPP leaders have either refused to recognize the existence of the consensus, refused to concede its legitimacy, or refused to agree that the consensus is good for Taiwan.

Those who claim that there is no 1992 Consensus say that the concept is a fiction made up by the former deputy minister of mainland affairs Su Qi. And if they do acknowledge something like a consensus reached by the two sides, they say it is not legitimate because it refers to a "one-China principle," which can only mean that Taiwan is part of China. They understand very well that the Nationalist government insists on the ROC being the "one China," but they do not believe that the consensus leaves any room for Taiwan to interpret "one China" differently. They think mainland China will monopolize the interpretation because it is much more powerful and resourceful than Taiwan in the international community. ${ }^{19}$

The official statement of Tsai Ing-wen in 2000, who served as the minister of the Mainland Affairs Council during Chen Shui-bian's administration, was very typical of the DPP's position on this issue: “The so-called 'one China, differing interpretations' is only a usage by our side to describe the process of the meeting. It is a way of description that the new government can accept, but it does not mean that we have accepted Beijing's 'one-China principle." ${ }^{20}$ In 2003, she reinforced her stand on the issue by emphasizing that the ROC and the PRC did not belong to each other. "One side, one country," she emphasized, "is a statement of fact."

When Tsai ran for president in 2012, she tried to eliminate Taiwanese people's Chinese identity by promoting Taiwanese identity as its substitute. She maintained: "The Republic of China is an exile (alien) government, which rules Taiwan at the moment. The Chineseness of the ROC must be relocated from a subjective status to an objective status, and yields to Taiwaneseness." She also tried to persuade the general public to think of the cross-Strait relation in a novel way: "There is no 1992 Consensus. What I propose is to create a Taiwan consensus to replace the 1992 Consensus, which would be ratified by legislation and a referendum. This new consensus should then form the basis for negotiations with the PRC." 
Tsai lost the 2012 presidential election. Many political analysts believe that her failure to prove the feasibility of the Taiwanese Consensus was a salient, if not the most important, reason. It explains why she decided not to employ the terminology again during the 2016 presidential campaign. Yet she has been as unwavering as before on the issue of the 1992 Consensus. With the prospect that the DPP might win both the 2014 local elections and the 2016 general election, she was confident enough to believe that even the PRC would yield to her view about the 1992 Consensus afterwards. She said in an interview: "Whoever has power, different parties will shift their direction toward those with power. The DPP's biggest challenge is to do well in this year's local elections. If we do well, even China will shift in the direction of the DPP. If they feel that the DPP has the best chance of winning in 2016, they will automatically create the conditions for that." ${ }^{21}$

With this confidence, Tsai was ready to appeal to the majority who favored the status quo without endorsing the 1992 Consensus. Her successful strategy in the 2016 presidential election was to replace the unwelcome "Taiwan Consensus" with the popular "maintaining the status quo" but not to discuss what "the status quo" actually meant. In her speech at the Center for Strategic and International Studies on June 3, 2016, she repeated that maintaining the status quo "serves the best interest of all parties concerned," and she vowed to be "committed to a consistent, predictable, and sustainable relationship with China." She also emphasized that, if elected, she would "push for the peaceful and stable development of cross-Strait relations in accordance with the will of the Taiwanese people and the existing ROC constitutional order" (my italics). Nevertheless, when asked by the audience to elaborate her views on the issue and explain how her thesis could be reconciled with the DPP's independence platform, she refused to explain further and only asked them to carefully read her speech again. ${ }^{22}$

Maintaining the status quo, as we point out in the previous section, has remained the favorite option of the majority in Taiwan. However, "the status quo" can mean different things to different people. Some think the status quo is a country called the Republic of China, which agrees with mainland China that both sides can interpret their concept of China respectively. Some think the status quo is a separate country called Taiwan, which has never agreed with China regarding the idea that there is only "one China" under which they should be subsumed. As Ma Ying-jeou reiterated several times, the status quo for most Taiwanese is a peaceful cross-Strait relationship created by his policy of three nos-"no unification, no independence, and no use of military force" under the framework of the ROC constitution. It is also a result of cross-Strait dialogues based on the 1992 Consensus (namely, "one China, differing interpretations"). If Tsai Ing-wen's "status quo" was similar to the status quo that Ma created, he would be very glad to have the leader of the opposition party follow his own mainland policy. ${ }^{23}$ Unfortunately, Tsai is clear that she will not accept the 1992 Consensus or agree that Taiwan and 
TABLE 2 Different players' conception of the "one-China principle"

\begin{tabular}{lcccc}
\hline & China & KMT & USA & DPP \\
\hline There is only one China in the world. & X & X & X & X \\
Taiwan is part of China. & X & X & X & \\
"China" can be interpreted differently. & $?$ & X & & \\
China is represented by the PRC. & $\mathrm{X}$ & & $\mathrm{X}$ & $\mathrm{X}$ \\
China is represented by the ROC. & & $\mathrm{X}$ & & $\mathrm{X}$ \\
$\begin{array}{l}\text { Taiwan is not part of China. } \\
\text { China and Taiwan are two countries. }\end{array}$ & & & $\mathrm{X}$ \\
\hline
\end{tabular}

the mainland belong to the same China, even though that is the frame of the ROC constitution. She is going to change the status quo and pretend that she does not.

Tsai now acknowledges that there was a talk between the two sides of the Taiwan Straits in 1992, but she still does not acknowledge that a consensus was reached by the two sides. This minor revision of her original position on the 1992 Consensus appeared shortly before Election Day and reappeared in her inaugural address on May 20, 2016. She asserted, "There was a bilateral summit in 1992 as a matter of historical fact and there was a mutual cognizance of 'seeking common ground while shelving differences." Nevertheless, she refused to concede that the "common ground" was the 1992 Consensus or "one China, different interpretations," let alone the idea that Taiwan is or will be part of China, no matter what "China" means. Beijing responded immediately that this was not the answer "to the examination" (i.e., not the right answer), but apparently the CCP is willing to wait until Tsai changes her mind in the near future.

Before we end this section, it may be helpful to illuminate different players' position regarding the "one-China" question (table 2): From this table, we can see how that four concerned actors (China, USA, KMT, DPP) can agree on the unspecified statement that "there is only one China in the world," while still differing dramatically on the related components of the "one-China" question. It also explains why the simple statement "There is only one China in the world" cannot be easily developed into either a "one-China policy," a "one-China principle," a "one-China framework," or any terminology that includes "one China." In Taiwan, the really divisive issue is not national identity nor the choice of unification or independence but the meaning and implications of "one China."

\section{PROSPECTS OF CROSS-STRAIT RELATIONS}

The problem of cross-Strait relations is never restricted to Taiwan and mainland China alone. It involves the PRC, the ROC, and the United States, and within the 
ROC it is an issue of contention between the KMT and the DPP. Therefore, it can be described as a strategic triangular relationship concerning four key players. Understanding this complex issue requires considering the position of each player, as well as players' interactions and chains of reaction.

In international relations theory, the interaction between the PRC, the Soviet Union (later, Russia) and the United States is regarded as a typical "great strategic triangle," while the interaction between Beijing, Taipei, and Washington can be conceived as a small strategic triangle. It is a triangular relation because the ROC needs the United States to resist the political and military pressure of the PRC, the PRC needs the United States' tacit support to prevent the ROC from seeking de jure independence, and the United States wants the PRC and the ROC to constrain their hostility ${ }^{24}$ Furthermore, the small strategic triangle is unbalanced in that the power and influence of the PRC and the United States are disproportionally superior to the ROC's. As Yu-shan Wu points out, when the power between two actors is asymmetrical, the interpretation and prediction of the two actors' moves should also be adjusted correspondingly. Power asymmetry also affects other variables, such as motivation for economic integration, probability of military confrontation, shifts in national identity, strategy of electoral campaigns, and so forth. ${ }^{25}$

With this framework in mind, we may now begin to analyze what the four actors pursue and avoid with regard to cross-Strait relations. The PRC wishes to complete its unification enterprise in the twenty-first century, especially under the guideline of Chairman Xi Jinping's “Chinese Dream” of attaining wealth, power, and modernization for China as a whole. The PRC realizes that more and more Taiwanese are embracing a Taiwanese consciousness and favoring independence, even though maintaining the status quo still remains the majority's priority for the moment. To keep Taiwan from moving forward to de jure independence, the PRC is keen to reach a political agreement between the two sides that formally acknowledges the principle that there is only one China in the world and that both the mainland and Taiwan are parts of China. But when Ma's government was politically challenged after the intraparty conflict with Speaker Wang in 2013 and the turbulence of the Sunflower Movement in 2014, it virtually lost the momentum to negotiate any political agreement with mainland China, whether a "framework of peace agreement" or a "mechanism for military mutual trust." With the DPP's overwhelming victory in the 2016 election, the best result the PRC can expect is to secure the 1992 Consensus and assent to the principle of "one China" in no more than a vague sense. If this minimum expectation cannot be fulfilled, Xi Jinping may have to consider other options. It is not to the PRC's advantage to confront the United States when China has many more important goals to achieve, but the Taiwan independence issue is too serious to be neglected. Xi definitely does not want to become the leader in Chinese history who loses Taiwan: this would be a devastating blow to his own political life and the legitimacy of the CCP. 
The challenge, therefore, is to secure US cooperation in preventing the DPP from nullifying the 1992 Consensus.

In the KMT, former president Ma and his political allies believe that the 1992 Consensus (in the sense of "one China, differing interpretations") is the best policy for cross-Strait relations. However, the current chair, Ms. Hung Hsiu-chu, obviously has a quite different conception of cross-Strait relations. Hung accuses the DPP of pushing for Taiwanese independence in the name of democracy and predicts that this will "bring threats to national security, make Taiwan even more isolated, cause economic stagnation, and fuel hatred in society." Yet she was not satisfied with the current "one China, differing interpretations" policy either. She asserted that the best policy for cross-Strait relations should be "one China, same interpretation" (yizhong tongbiao) and said Taiwan should sign a peace agreement with mainland China on the precondition that the ROC constitution be upheld and the will of the people respected. ${ }^{26}$ Hung's statement is generally viewed as supportive of unification and immediately causes suspicion and criticism among the KMT politicians who feel more comfortable with Ma's "three nos." To ease intraparty opposition, Hung argues that her policy is merely "enhancing" the 1992 Consensus rather than "replacing" it. Nevertheless, it is becoming more and more clear that she is not going to continue Ma's policy. Her move toward unification will help the DPP appear more like an advocate of the status quo. How Beijing will react to Hung's proposal is yet to be seen.

As for the DPP, Tsai Ing-wen's major challenge is to persuade the Taiwanese people, the PRC, and the United States that she will not pursue de jure Taiwan independence during her presidential term. What she needs to accomplish on this tough question is to find a subtle balance between the DPP's "Taiwanese Independence Platform" (which proposes the drafting of a new constitution and the establishment of a Republic of Taiwan) and the general public's concern about the risk of war if the DPP pursues Taiwanese independence or amends some critical articles of the current constitution. Tsai's repeated announcement of "maintaining the status quo" is an attempt to assure the people that she will neither pursue outright independence nor try to amend the ROC constitution in favor of independence. Nonetheless, her DPP supporters (especially the "fundamentalists," or hard-liners on the independence issue) will complain that there is no difference between her position and Ma's. Ever since her inauguration, she has been careful not to challenge mainland China directly, but her consistent denial of the 1992 Consensus, her shifting position on the South China Sea controversy, her apathy toward the Chinese victims who died in a mysterious bus accident in Taiwan, her appointment of several proindependence grand justices to the Supreme Court, and her tacit support of the Hong Kong independence movement all make the CCP suspect her sincerity about maintaining the status quo. As many cross-Strait relation experts observe, Tsai is pursuing Taiwanese independence under the 
(temporary) cover of the ROC, a strategy that may satisfy the United States but cannot win the trust of China.

Finally, the role of the United States is always essential. In the small strategic triangle of Beijing-Taipei-Washington, the United States seems more like a pivot than merely a partner. The US stake in this issue is to maintain peaceful and stable cross-Strait relations, without any unexpected unilateral political or military moves. The missile-test crisis of 1996 was solved by the deployment of American aircraft carrier battle groups in this region. The "one country on each side" controversy and independence referendum initiated by Chen Shui-bian was rebuked by the US government. From the way Washington has interfered and managed various crises in the past, it is clear that the United States prefers a no-surprise, low-risk status quo in this region. To date, the United States seems to welcome Taiwan and the mainland to continue dialogue on the basis of Beijing's assertion that there is only one China and that only one government can legitimately represent it, and to insist that the solution to cross-Strait antagonism must be peaceful. It does not support any unilateral action to seek Taiwanese independence; neither does it publicly endorse the 1992 Consensus or the "one China, differing interpretations" policy. However, as the rise of a powerful China becomes more and more threatening, many observers begin to wonder if the United States will change its position and encourage Taiwan to keep a greater distance from China. Some DPP leaders actually think that even if Taiwan moves toward independence, the US response may change from that of 2002-4 simply because the United States and the PRC have so many conflicts of interest in the East China Sea and the South China Sea. Yet for the very same reason the PRC may urge the United States to clarify its position on "one China" in the years to come. As Huang Jing indicates, Xi Jinping has consistently maintained that Taiwan is a core interest of China, and he will not allow Taiwan to be the bargaining chip in negotiations over the PRC's new relationship with the United States. ${ }^{27}$ After so many years' experience of interaction, Beijing has become increasingly convinced that the United States is reliable about "not supporting Taiwanese independence." ${ }^{28}$ What remains to be seen is the extent to which the PRC will tolerate the United States' taking advantage of anti-China sentiment among the Taiwanese and tacitly endorsing the DPP's assertion that Taiwan is not part of China. From Washington's perspective, continuing its support of cross-Strait dialogue on the basis of the 1992 Consensus means stability in the East Asia, but Taiwan may become more tied to mainland China. On the other hand, encouraging a new cross-Strait policy without the 1992 Consensus opens up some novel strategic possibilities for relations between the United States and its East Asian associates, but it also involves the risk of Beijing's retaliation. Washington's judgment and decision on this issue will be of great significance for the future development in this region. 
Cross-Strait relations are very complicated and unpredictable. When Ma Yingjeou was elected as Taiwan's president, he was determined to improve relations with mainland China and successfully reached dozens of agreements between the two sides. The scenario during his first term of presidency was so rosy that some scholars even speculated about the possibility of drafting a peace agreement between the PRC and the ROC. ${ }^{29}$ Yet only a couple of years later the Taiwanese people expressed their deep worry and suspicion about the pace of cross-Strait rapprochement. ${ }^{30}$

In the past eight years, cross-Strait relations stayed relatively peaceful and stable compared with the period of 2000-2008 because the two sides could carry out constructive dialogues and cooperation under the 1992 Consensus. But now that the DPP has regained political power, commentators have begun to consider the unpleasant possibility of military confrontation. As Scott L. Kastner reminds us, "It is possible to imagine a number of future events-ranging from a return of the DPP to power in Taiwan, to continued growth in Taiwan-centric identity despite deepening cross-Strait economic integration, to a period of economic malaise in the PRC-that could lead to renewed pessimism in Beijing about long-term trends in the Taiwan Strait." If any of these scenarios comes true, a "preventive war fought to alter unfavorable long-term trends" cannot be excluded. ${ }^{31}$ Although Kastner thinks there are reasons to be optimistic about the future of cross-Strait relations in the short to medium term, he admits that the current détente requires continual careful management. ${ }^{32}$

What will happen if the Tsai administration continues to reject the 1992 Consensus? This is a difficult question to answer. The PRC has many tools to compel the DPP back to the "one-China" track, including diplomatic, economic, political, and military measures. Diplomatically, the PRC can carry out a surprise attack on Taiwan by asking several countries to immediately cut official relations with Taiwan or by withdrawing its support of Taiwan's participation in international organizations. ${ }^{33}$ Economically, the PRC can tighten the financial supply of Taiwanese enterprises doing business with China, restrict importation of Taiwanese goods and services to China, or trim down the quota of Chinese tourists visiting Taiwan. Politically, it can cancel all cross-Strait negotiations, meetings, academic cooperation, sporting events, and cultural exchanges. Militarily, it can fire missiles again over the island, perform military operations around Taiwan's harbors, intrude into the Air Defense Identification Zone, or send aircraft carriers and naval vessels to patrol in the Taiwan Strait. These measures may prove counterproductive and arouse more anger and resentment than fear among Taiwanese people, but it could be hard for the PRC to act differently.

Some of the measures will hurt Taiwan only, others may make the United States nervous and give it no choice but to respond with similar measures. The situation may not deteriorate into a comprehensive war between China and the United 
States (and its East Asia allies), but a certain kind of political deadlock or military confrontation is not altogether impossible. Since Tsai's inauguration, China seems to be exercising a gradual escalation strategy of putting pressure on Taiwan, rather than employing all its tools at hand. It is unlikely that China will use its military power against Taiwan as long as Tsai avoids any explicit policy of Taiwan independence, yet there is no sign of China's concession to Tsai's rejection of the 1992 Consensus either. A new détente may be the best description of cross-Strait relations in years to come.

\section{CONCLUSION}

The national identity of Taiwan and its impact on cross-Strait relations might seem to be a "domestic" issue of Taiwan, or at most a bilateral issue between Taiwan and China. But as I have shown, this problem has a much more far-reaching effect than is apparent at first glance. It not only reflects the positions of different parties in Taiwan on the unification/independence question but also concerns the realization of Xi Jinping's "Chinese Dream." It does not merely involve the United States in the sense of consolidating a maritime alliance against China but also bears on the structural transformation of superpowers in the twenty-first century. ${ }^{34}$ If we do not pay enough attention to the political consequences of a seemingly "domestic" issue of a small island country, we will not be able to cope with one of the most difficult challenges East Asia faces now.

National identity is an equivocal concept in political theory. Sometimes it means one's sense of belonging to a specific ethnic or cultural community; sometimes it means one's self-identity as a member of a particular state. Nationalist scholarship tends to combine the two elements in order to portray or predict the formation of a nation-state, but such a move is not warranted because consciousness of a cultural group is not always consistent with identity of a political community. To presuppose that the political unit and the cultural unit should be congruent is a misleading starting point in the study of national identity.

All three of the popular methods of measuring national identity in Taiwanthe Chinese/Taiwanese/both identity measure, the unification/independence measure, and the "Chinese Nationalist versus Taiwanese Nationalist" measurereveal important information about the collective consciousness of Taiwanese, but none of these adequately describe the political identity of the people living on the island. I therefore recommend a fourth method that is frequently ignored in Taiwan studies: the method of assessing how respondents delineate their compatriots and homeland. Measuring in this way, we find that Taiwan's national identity is not as divisive an issue as many scholars or politicians describe. The people of Taiwan may differ at being Chinese or Taiwanese, and they may disagree about their political future (to unify with China or seek independence), but most of them favor 
the status quo (neither unification nor independence), and perhaps more than 85 percent of them have a clear identity as to which country they belong to.

But although national identity per se is not a real or pressing issue in Taiwan, the question of how to deal with the one-China principle embedded in the 1992 Consensus is a real problem. Ma's government successfully signed twenty-one agreements with mainland China on the basis of the 1992 Consensus during his administration. The DPP endorses the signed agreements but refuses to negotiate with the PRC any more on the precondition of the 1992 Consensus. The DPP's new mainland policy and the CCP's reaction will affect stability in East Asia and destabilize further the already edgy PRC-US relationship.

There are several possible ways to ease tensions across the Taiwan Strait. One would be to convince Tsai Ing-wen and the DPP that it would be good for Taiwan to maintain cross-Strait relations on the basis of the 1992 Consensus, but Xi Jinping or the PRC would need to acknowledge the "differing interpretations" part of the consensus in addition to its favorite "one-China" part. In this case, Tsai might be able to maintain the status quo by adhering to the name of ROC. Another possibility would be for the United States and the PRC to finally agree that the 1992 Consensus is not the only formula for securing peace and stability in the Taiwan Strait, and for Tsai to provide an innovative, practicable, and convincing new policy. This would mean the end of the era of the 1992 Consensus and the beginning of a new age whose direction no one can predict at the moment. The third solution would be to invite all concerned parties to deliberate on the changing meaning of "one China" and to figure out if any better definition or interpretation could satisfy the purposes of all parties. It is difficult to say which solution would produce the best possible outcome. But all concerned parties should do their best to prevent the escalation of political tension and to secure sustainable peace among peoples.

\section{NOTES}

1. Some of the most influential scholarly works on nationalism in Taiwan are E. J. Hobsbawn, Nations and Nationalism since 1780: Programme, Myth, Reality (Cambridge: Cambridge University Press, 1990); Benedict Anderson, Imagined Communities: Reflections on the Origin and Spread of Nationalism, 2nd ed. (London: Verso, 1991); Anthony D. Smith, National Identity (Reno: University of Nevada Press, 1991). Important Taiwanese scholarship includes Zhang Maugui, ed., Zuqun guanxi yu guojia rentong [Ethnic relations and national identity] (Taipei: Yueqiang, 1993); Lin Jialung and Zheng Yongnian, eds., Minzu zhuyi yu liangan guanxi [Nationalism and cross-Strait relations] (Taipei: New Naturalism, 2001); and Hsiau A-chin, Chonggo Taiwan: Dangdai minzuzhuyi de wenhua zhengzhi [Reconstructing Taiwan: The cultural politics of contemporary nationalism] (Taipei: Linking, 2012).

2. For further discussion of the different approaches to nationalism, see John Breuilly, "Approaches to Nationalism," in Mapping the Nation, ed. Gopal Balakrishnan (London: Verso, 1996), 149-59, and Anthony D. Smith, The Nation in History: Historiographical Debates about Ethnicity and Nationalism (Hanover, NH: University Press of New England, 2000), 27-51.

3. See Yi-huah Jiang, "Is Taiwan a Nation? On the Current Debate over Taiwanese National Identity and National Recognition," in The Dignity of Nations: Equality, Competition, and Honor in East 
Asian Nationalism, ed. Sechin Y.S. Chien and John Fitzgerald (Hong Kong: Hong Kong University Press, 2006), 141-64.

4. Earnest Gellner, Nations and Nationalism (Ithaca, NY: Connell University Press, 1983), 1.

5. Hui-ling Chen, "Taiwanese/Chinese Identification Trend Distribution in Taiwan (1992/06 2016/12)," Election Study Center, National Chengchi University, August 24, 2016, http://esc. nccu.edu.tw/course/news.php?Sn=166. See also Chu Yun-han, "Navigating between China and the United States: Taiwan's Politics of Identity," in Taiwanese Identity in the Twenty-First Century: Domestic, Regional and Global Perspectives, ed. Gunter Schubert and Jens Damm (London: Routledge, 2011), 141-48, with an emphasis on the change during Chen Shui-bian's administration, and Christopher R. Hughes, "Revisiting Identity Politics under Ma Ying-jeou," in Political Changes in Taiwan under Ma Ying-jeou: Partisan Conflict, Policy Choices, External Constraints and Security Challenges, ed. JeanPierre Cabestan and Jacques deLisle (London: Routledge, 2014), 130-32, with an emphasis on developments during Ma's administration.

6. See Jiang Yi-huah, "Xin guojia yundong xia de Taiwan rentong" [Taiwanese identity in the movement to create a new country], in Lin Jialung and Zheng Yongnian, Minzu zhuyi yu liangan guanxi, 202-3. A similar problem also occurs on the part of "being Taiwanese." Jean-Pierre Cabestan, in chapter 3 of this book, reminds us that the survey of the Chinese/Taiwanese identity "has a major weakness: it does not make any distinction between cultural and political identities."

7. Hui-ling Chen, "Taiwan Independence vs. Unification with the Mainland Trend Distribution in Taiwan (1992/06 2016/12)," Election Study Center, National Chengchi University, http://esc.nccu.edu. tw/course/news.php?Sn=167. See also Chen Luhui and Geng Shu, "Taiwan minzhong tongdu lichang de chixu yu bianqian" [The continuity and change of Taiwanese people's attitude toward unification/ independence], in Chong xin jian shi zheng bian zhong de liang an guan xi li lun [Revisiting theories on cross-Strait relations], ed. Bao Zonghe and Wu Yushan, 2nd ed. (Taipei: Wunan Press, 2012), for a more detailed analysis of different generations' stance on this issue. Needless to say, the composition of those preferring the status quo has changed dramatically over time. Many supporters of the status quo come from former unification supporters, while many who used to maintain the status quo have become independence supporters.

8. See Jiang Yi-huah, Ziiu zhui, minzu zhui yu guojia rentong [Liberalism, nationalism, and national identity] (Taipei: Yangzhi Press, 1998), 217-21; Jiang Yi-huah, "Xin guojia yundong xia de Taiwan rentong," 203-5. To further explore what "maintaining the status quo" means, many scholars have tried to add more conditional questionnaires; see Ching-hsin Yu, "National Identity in Taiwan: A Revisit," paper presented at the Second World Congress of Taiwan Studies, School of Oriental and African Studies (SOAS), University of London, June 18-20, 2015.

9. For the following discussion, see Wu Nai-teh, "Shengji yishi, zhengzhi zhichi he guojia rentong" [Provincial consciousness, political support and national identity], in Zhang Maugui, Zuqun guanxi yu guojia rentong; Shiau-chi Shen and Nai-teh Wu, "Ethnic and Civic Nationalisms: Two Roads to the Formation of a Taiwanese Nation," in The "One China" Dilemma, ed. Peter C. Y. Chow (New York: Palgrave Macmillan, 2008), 120-24.

10. Shen and Wu, "Ethnic and Civic Nationalisms," 123-24. Yun-han Chu offers a similar analysis but interestingly terms the four categories "principled believers in independence," "principled believers in unification," "open-minded rationalists," and "strong believers in the status quo." See Yun-han Chu, "Taiwan's National Identity Politics and the Prospect of Cross-Strait Relations," Asian Survey 44, no. 4 (July/August 2004): 504-6.

11. See Jiang Yi-huah, Ziiu zhui, 172. See also Yu, "National Identity."

12. See Liu I-chou, "Taiwan minzhong de guojia rentong: Yige xinde celiang fangfa" [National identity of Taiwanese people: A new measurement], paper presented at the annual meeting of the Chinese Political Science Association, Taipei, 1998.

13. Qualitative research through focus group interviews has been conducted, but further investigation is needed; see Yu, "National Identity." 
14. Fang Chou, Yu zhongguo wuguan [Nothing to do with China] (New Taipei City: Baqiwuhua, 2014), 34 .

15. Su Qi and Cheng Ankuo, eds., "Yige zhongguo, gezhi biaoshu": Gongshi de shishi [One China, differing interpretations: A historical account of the 1992 Consensus], 2nd ed. (Taipei: National Policy Foundation, 2011), 203-4. The resolution of the National Unification Council reads: "Both sides of the Taiwan Strait uphold the principle that there is but one China. However, the two sides hold different interpretations of that principle."

16. Ibid., 204.

17. For detailed background on this, see Su Qi, preface to ibid., v-xii.

18. Su Qi and Cheng Ankuo, "Yige zhongguo," 16-17. James Kelly's testimony runs as follows: "The 1990 ushered in a decade of incremental consensus-building. Both sides agreed in 1992 that there was one China, but left each side free to express their interpretation of the concept."

19. For an interesting defense of denial and criticism of the 1992 Consensus in the Pan-Green coalition (the proindependence alliance formed in Taiwan after the 2000 elections between the DPP, the Taiwan Solidary Union, and the Taiwan Independence Party), see Wu Jiemin, "Zhongguo insu yu liangan gongmin shehui duihua" [The China factor and dialogues between civil society across the Strait], in Wenming de huhuan: xunzhao liangan heping de jichu [Civility and peace dialogue], ed. Tsen Guoxiang and Xu Siqin (New Taipei City: Zuoan wenhua, 2012), 280-88.

20. Quoted in Su Qi and Cheng Ankuo, "Yige zhongguo," 82. The statement is actually a reversal of President Chen's earlier statement that the DPP government was willing to negotiate with China on the basis of the 1992 Consensus.

21. Sara Wu, Jung-Shin Ho, and Hsiao-Wen Wang, "Tsai Ing-wen: Election Win Will Shift China toward DPP," Commonwealth magazine, July 10, 2014.

22. Tsai Ing-wen, "Taiwan Meeting the Challenges Crafting a Model of New Asian Value," June 4, 2015, Center for Strategic and International Studies, Washington, DC, http://csis.org/event/ tsai-ing-wen-2016.

23. For Ma’s speech on his mainland policy, see "President Ma's Speech Reaffirms the 1992 Consensus," Central News Agency, April 29, 2015, www.cna.com.tw/news/firstnews/201504290149-1.aspx.

24. See Lowell Dittmer, "Triangular Diplomacy amid Leadership Transition," in Chow, "One China" Dilemma, 179.

25. See Yu-Shan Wu, "Under the Shadow of a Rising China: Convergence towards Hedging and the Peculiar Case of Taiwan," in Globalization and Security Relations across the Taiwan Strait: In the Shadow of China, ed. Ming-chin Monique Chu and Scott L. Kastner (London: Routledge, 2015), 25-36; Wu Yu-shan, "Quanli buduichen yu liangan guanxi ianjiu" [Power asymmetry and cross-Strait relations studies], in Bao Zonghe and Wu Yu-shan, Chong xin jian shi zheng bian zhong de liang an guan xi li lun, 31-6o; see also Yu-Shan Wu's chapter 11 in this volume.

26. Shih Hsiu-chuan and Alison Hsiao, "KMT's Hung Criticizes DPP over Independence," Taipei Times, June 11, 2015, www.taipeitimes.com/News/front/archives/2015/06/11/2003620411.

27. See Huang Jing's chapter 13 in this volume.

28. Chu, "Taiwan's National Identity Politics," 494.

29. See Phillip C. Saunders and Scott L. Kastner, "Envisioning a China-Taiwan Peace Agreement," in New Thinking about the Taiwan Issue: Theoretical Insights into Its Origins, Dynamics, and Prospects, ed. Jean-Marc F. Blanchard and Dennis V. Hickey (London: Routledge, 2012), 153-71.

30. T. Y. Wang, Su-feng Cheng, Ching-hsin Yu, and Lu-huei Chen, "Structural Realism and Liberal Pluralism: An Assessment of Ma Ying-jeou’s Cross-Strait Policy," in Blanchard and Hickey, New Thinking, 142 .

31. Scott L. Kastner, "Rethinking the Prospects for Conflict in the Taiwan Strait," in Chu and Kastner, Globalization and Security Relations, 50-52.

32. See Ping-Kuei Chen, Scott Kastner, and William Reed's chapter 12 in this volume. 
33. China allowed Taiwan's low-profile participation in the 2016 World Health Assembly but canceled Taiwan's right to participate in the 2016 International Civil Aviation Organization meeting. It closed the door of the World Health Organization in 2017. In addition, two countries, São Tomé and Príncipe and Panama, have terminated their diplomatic relations with Taiwan and shifted to the PRC since Tsai's coming to power.

34. See Chu, "Taiwan's National Identity Politics," 484-512, for a similar reminder of the significance of the "domestic issue" for regional security. See also Chu Yun-han, Gaosi zaiyun: Yige zhishifenzi dui ershiyi shiji de sikao [Lofty thoughts on the cloud: An intellectual's reflection on the twenty-first century] (Taipei: Commonwealth, 2015), 29-35, 144-47, for a more detailed analysis of the transformation of the regional order in East Asia. 